\title{
Z historii spawania łukowego pod topnikiem
}

\section{The history of submerged arc welding}

\section{Streszczenie}

Spawanie łukowe pod topnikiem, nazywane też spawaniem łukiem krytym jest jedną z najbardziej wydajnych metod spawania. Pierwsze próby zastosowania ochrony topnikowej podejmowano w Rosji pod sam koniec XIX w., a więc faktycznie zanim upowszechniła się jakakolwiek technologia spawania. Rozkwit spawania pod topnikiem nastąpił podczas II Wojny Światowej, gdy zapotrzebowanie na masowo produkowane konstrukcje stalowe było ogromne. W Polsce tę metodę spawania zaczęto wdrażać dopiero w drugiej połowie lat 50. ub. wieku w dużej mierze za sprawą Instytutu Spawalnictwa z Gliwic, w którym konstruowano stosowne urządzenia, opracowywano i produkowano topniki oraz promowano tę technologię.

Słowa kluczowe: technologie spawalnicze; spawanie łukowe; spawanie łukiem krytym; spawanie pod topnikiem

\begin{abstract}
Submerged arc welding is one of most efficient welding methods. First attempts to use the flux protection of a welding arc were carried in Russia at the end of nineteenth century, in fact before any welding technology was introduced. The rapid growth of submerged arc welding occurred during the World War II, when a demand for mass produced steel made constructions was enormous. In Poland the method was introduced only in mid-fifties of the last century as a result of activities of Gliwice Welding Institute, where indigenous welding machines and fluxes were designed and produced, while the technology was strongly promoted.
\end{abstract}

Keywords: welding technologies; arc welding; submerged arc welding

\section{Wstęp}

Spawanie pod topnikiem powstało $w$ rezultacie rosnącego zaufania do technologii spawalniczych z jednej strony i zwiększających się potrzeb w zakresie wydajnego łączenia stalowych konstrukcji wielkogabarytowych - z drugiej. Spawanie płomieniowe, wdrażane od 1901 r., kiedy Picard opatentował acetylenowo-tlenowy palnik inżektorowy, szybko wykazało, że możliwe jest tworzenie złączy spawanych o zadawalających właściwościach mechanicznych, ale była to technologia o ograniczonej wydajności, niemożliwa do automatyzacji. Spawanie łukowe, opatentowane przez Benardosa i Olszewskiego wcześniej, bo w 1885 r., było potencjalnie bardziej obiecujące, ale przynosiło gorsze wyniki, aż do opracowania przez Kjellberga elektrod otulonych w 1907 r. Jednak także ta metoda nie nadawała się do automatyzacji.

Pierwsze próby zautomatyzowania procesu spawania podejmowano $w$ drugiej dekadzie $X X$ wieku i najbardziej perspektywiczną z nich było spawanie nieotulonym drutem, testowane m.in. przez firmę Kjellberga. Udało się stworzyć mechanizm podawania drutu elektrodowego oraz układ zapewniający ruch głowicy spawalniczej względem spawanego przedmiotu. Problemem nie do rozwiązania była jednak niska jakość spoin wynikająca z braku jakiejkolwiek ochrony łuku i jeziorka spawalniczego.

\section{Rosja i ZSRR}

Pierwszy pomysł ochrony strefy spawania łukowego należy do rosyjskiego inżyniera Nikołaja Sławianowa, absolwenta Wydziału Górniczego uniwersytetu w Petersburgu (program studiów obejmował metalurgię i budowę maszyn), a od 1881 r. pracownika Puszecznych Zawodow (fabryki artylerii) w Permie. To on usprawnił w 1888 r. metodę Benardosa, zastępując nietopliwą elektrodę grafitową topliwą elektrodą metalową, która była równocześnie źródłem materiału dodatkowego. W 1891 r. otrzymał stosowny patent i opublikował pierwszą broszurę na ten temat [1]. Opracował wiele innych rozwiązań i urządzeń, które z czasem stały się w spawalnictwie oczywistościami, np. obrotowy stół-manipulator spawalniczy. Jego koncepcja dalszego udoskonalenia spawania łukowego polegała na pokryciu strefy spawania warstwą kuleczek szklanych, których część topiłaby się pod działaniem ciepła łuku tworząc rodzaj żużla, chroniącego jeziorko i lico stygnącej spoiny [2]. Sławianow najpierw do łukowego spawania miedzi używał topnika - „fosforytowego oczyszczacza Ławrowa", ale zalecał jego dozowanie w niewielkiej ilości. W jego późniejszych opracowaniach z 1892 r. pojawia się wszakże zalecenie, aby „nadmiar żużla usuwać w stanie ciekłym za pomocą specjalnego czerpaka", co świadczy o tym, że stosował do spawania bardzo znaczną ilość topnika [3].

Dr inż. Tomasz Szulc - Politechnika Wrocławska.

Autor korespondencyjny/Corresponding author: tomasz.szulc@pwr.edu.pl 


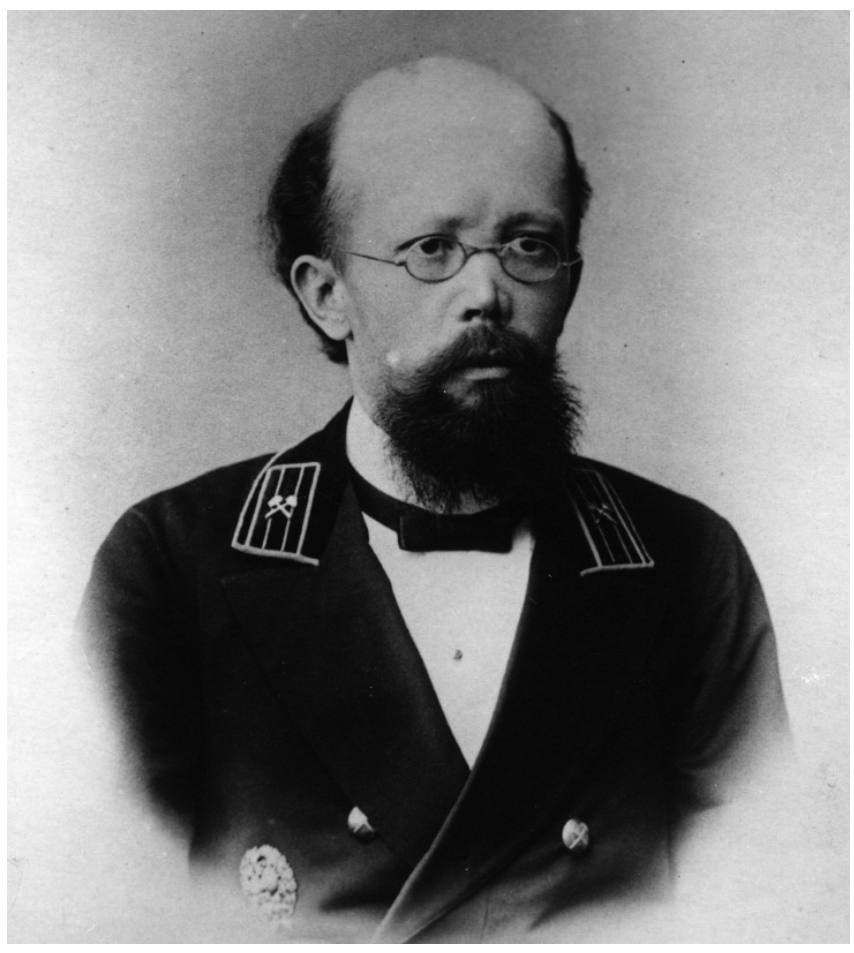

Rys. 1. Nikołaj G. Sławianow [3]

Fig. 1. Nikolay G. Slavyanov

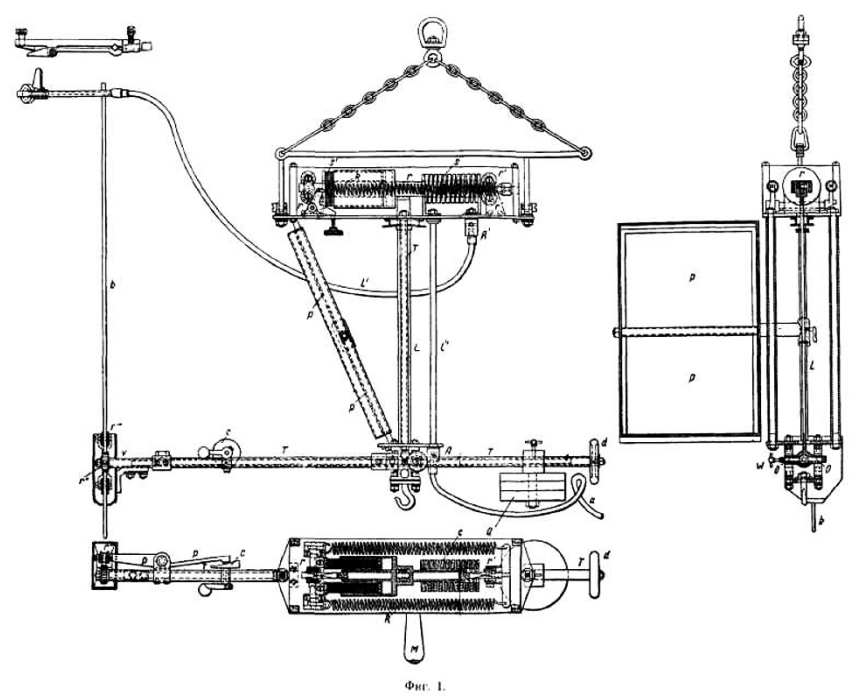

Rys. 2. Schemat pierwszego urządzenia Sławianowa do spawania elektrodą topliwą [2]

Fig. 2. Diagram of the first Slavianov's device for welding with a consumable electrode [2]

Po upływie 30 lat do pomysłu Sławianowa wrócił, już w ZSRR, D.A. Dulczewski. Pierwsze informacje o łukowym spawaniu "osłoniętym łukiem" publikował już w 1923 r., ale patent zgłosił 4 lata później i otrzymał dopiero w 1929 r. Dotyczył on spawania łukowego miedzi, a osłonę stanowić miała mieszanina węgla drzewnego, trocin, sadzy i skrobii [4]. Oznacza to, że wytwarzana przez tę mieszaninę osłona strefy spawania miała charakter gazowy, gdyż wszystkie komponenty „topnika” ulegały błyskawicznemu spaleniu w kontakcie z łukiem. Nie przewidywał także najwyraźniej automatyzacji spawania, gdyż w patencie pisał, że obserwację strefy spawania (przez spawacza) umożliwi „krater”, który utworzy się w warstwie topnika wokół elektrody.

W 1935 r. przy Akademii Nauk Ukraińskiej SSR utworzono Instytut Elektrosvarki (spawania elektrycznego), którego organizatorem i długoletnim dyrektorem został J. Paton. Jednym z głównych celów Instytutu było doskonalenie spawania łukiem krytym. W 1938 r. K. Chrunov opracował skład

\section{ПАТЕНТ НА ИЗОБРЕТЕНИЕ}

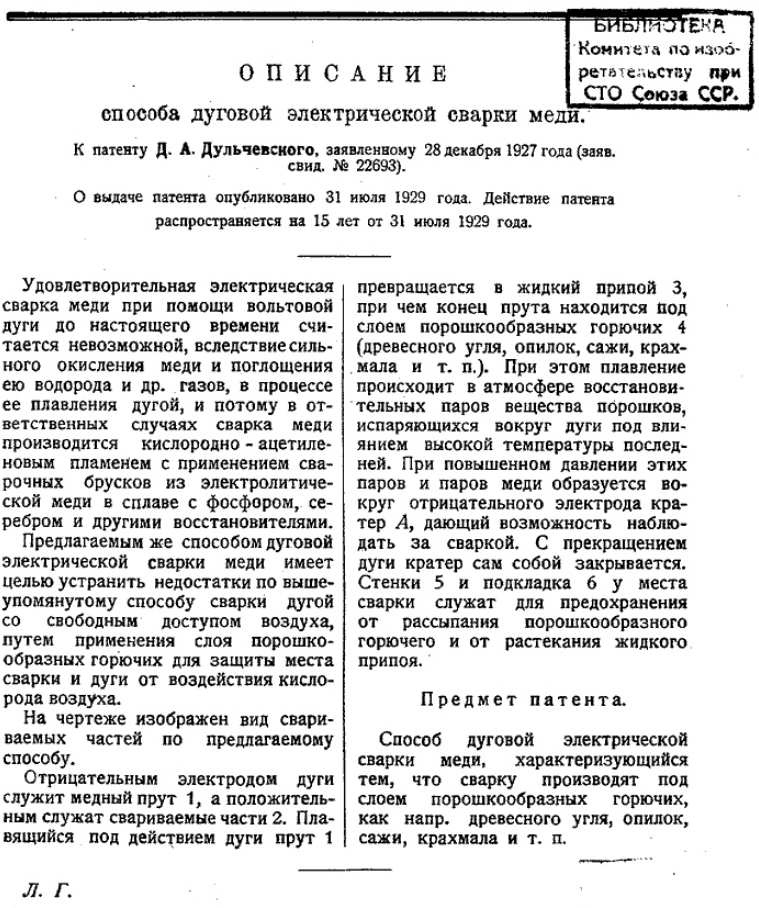

Rys. 3. Pierwsza strona patentu Dulczewskiego z 1929 r. [4]

Fig. 3. The first page of Dulczewski's 1929 patent [4]

\section{К патенту Д. А. Дульчевского 스 10578}

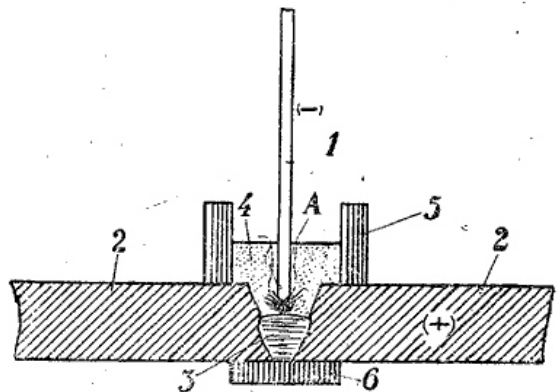

Rys. 4. Rysunek do patentu Dulczewskiego - widoczne są boczne okładki, zabezpieczające topnik przed rozsypaniem (stosowano je jeszcze na pocz. lat 50. ub. wieku) [4]

Fig. 4. Drawing for Dulczewski's patent - lateral covers protecting the flux against scattering are visible (they were still used at the beginning of the 1950s) [4]

i technologię produkcji topnika ceramicznego [5].

W grudniu 1940 r. wobec nieuchronnej konfrontacji z III Rzeszą zarządzono wdrożenie tej technologii w 20 kluczowych fabrykach w ZSRR. W 1941 r. Instytut ewakuowano do Niżnego Tagiłu, dokąd trafili również pracownicy i maszyny wielkiej fabryki czołgów z Charkowa. Ułatwiło to ścisłą kooperację obu instytucji. W 1942 r. W. Diatlov złożył wniosek wynalazczy, dotyczący wyjaśnienia zasady samoregulacji długości łuku elektrycznego wskutek częściowego przewodzenia prądu spawania przez stopiony topnik [6]. Dzięki temu zjawisku można było zrezygnować ze skomplikowanego sterowania prędkością podawania drutu napięciem łuku.

Prawdziwą chwilą prawdy dla spawania łukiem krytym w ZSRR była Druga Wojna Światowa, a konkretnie starcie dwóch najpotężniejszych machin wojennych w Europie: Wehrmachtu i Armii Czerwonej. O losach tego starcia decydowały w dużej mierze czołgi, które obie strony traciły tysiącami. O tym, kto zwycięży, decydowało także i to, kto będzie 


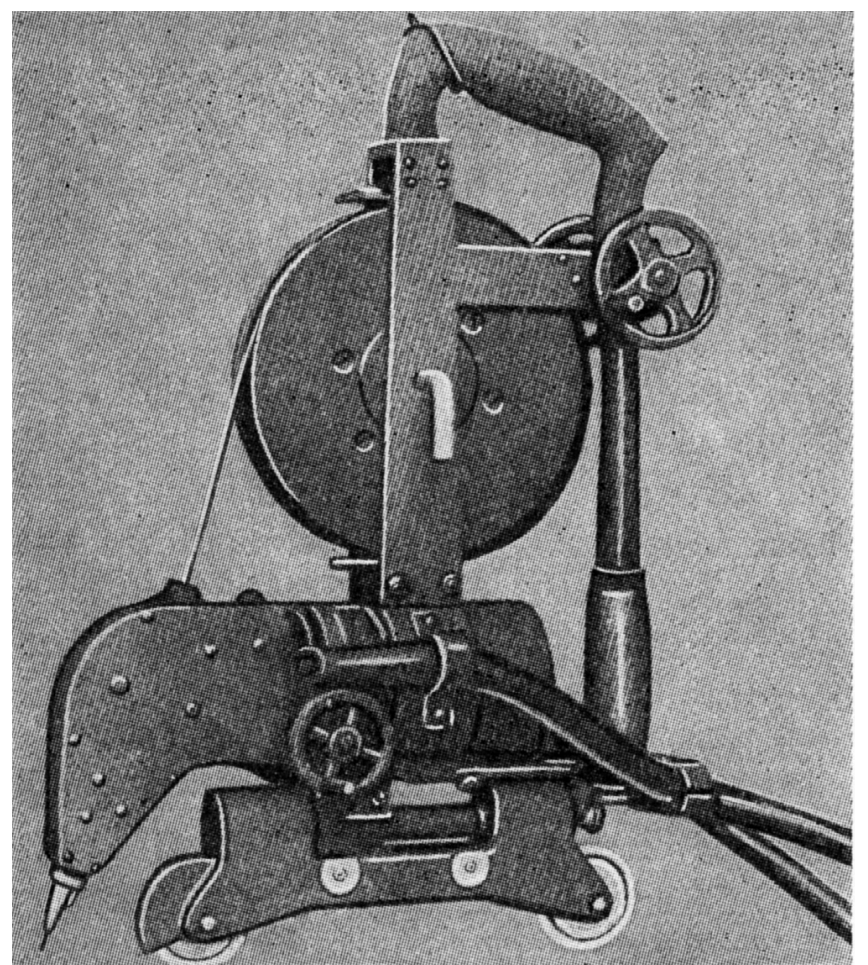

Rys. 5. Automat "stołowy" do spawania łukowego nieosłoniętym drutem - poprzednik automatów do spawania lukiem krytym [17] Fig. 5. Table welding machine for arc welding with bare wire - predecessor of submerged arc welding machines [17]

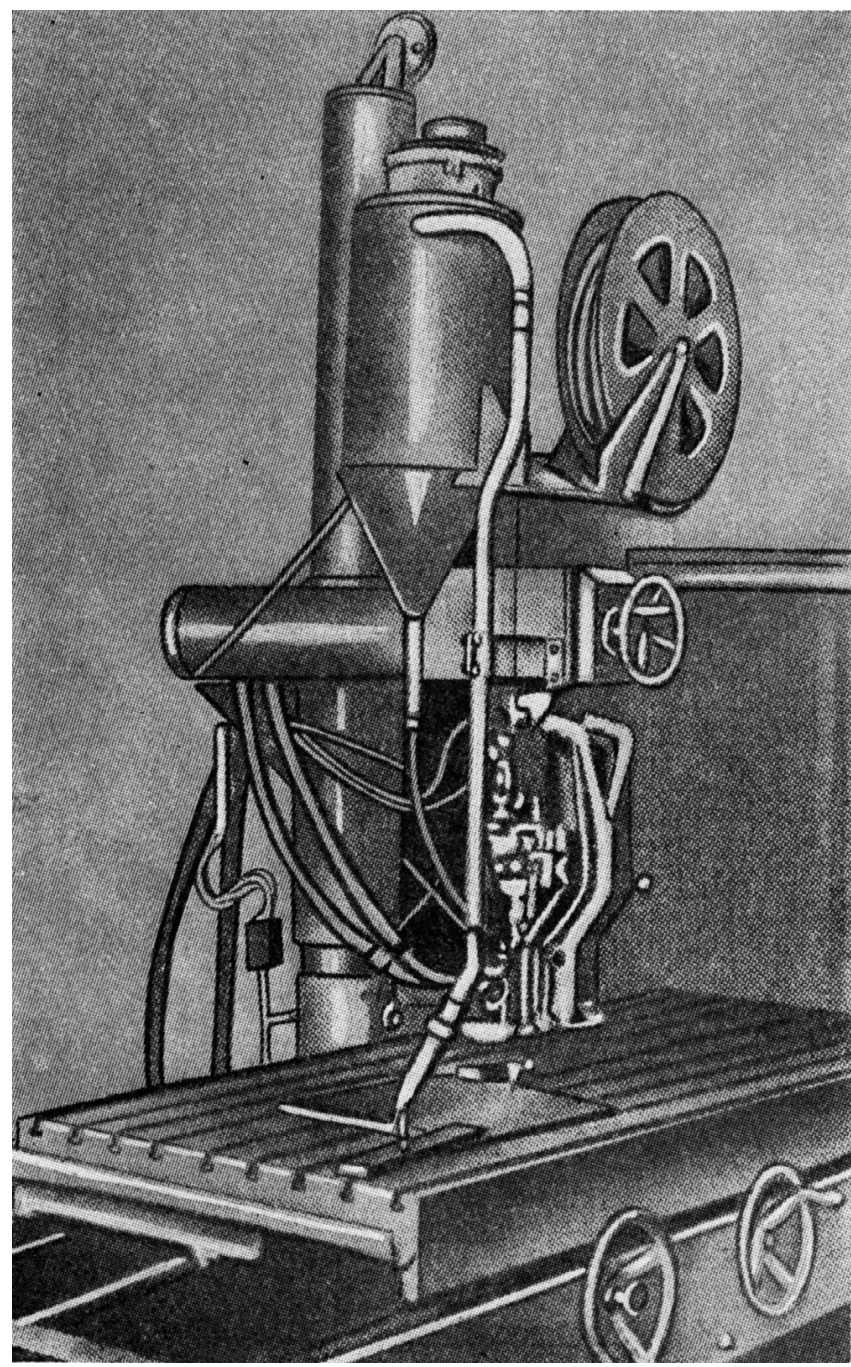

Rys. 6. Pierwszy seryjny automat do spawania łukiem krytym z początku 1941 r. opracowany przez Instytut Elektroswarki z Kijowa [17] Fig. 6. The first serial submerged arc welding machine from the beginning of 1941 developed by the Electroswarki Institute from Kiev [17] je szybciej i wydajniej produkował. Czołgi niemieckie, zapewne najlepsze wówczas na świecie, powstawały w wyniku zastosowania sprawdzonej technologii - ręcznego spawania elektrodami otulonymi. Pracowały przy tym rzesze wysoko kwalifikowanych spawaczy - mężczyzn, którzy byli tak potrzebni na froncie. W Związku Radzieckim kadłuby wozów bojowych spawano łukiem krytym - tylko majstrami byli mężczyźni, a wymianą szpul z drutem oraz uzupełnianiem topnika zajmowały się kobiety i nastolatki bez technicznego przygotowania. Istotna była także pracochłonność: od wycięcia z blachy pierwszych elementów, do opuszczenia fabryki przez czołg T-VI Tiger upływały trzy miesiące [7]. Ten sam proces $w$ przypadku czołgu T-34 zajmował 8 dni [8]. Dzięki temu Rosjanie mogli nie tylko uzupełniać straty, ale i błyskawicznie rozbudowywać jednostki pancerne, które ostatecznie wygrały wojnę w Europie. W ten sposób spawanie łukiem krytym, jak żadna inna technologia spawalnicza, bezpośrednio wpłynęło na historię i losy świata.

Na początku 1941 r. w fabryce czołgów w Tagile pracowato 19 stanowisk spawalniczych z automatami do spawania pod topnikiem, rok później także w fabryce w Czelabińsku działały 32 takie stanowiska. Zużycie energii elektrycznej po ograniczeniu spawania elektrodami otulonymi spadło o ponad $40 \%$. Zrezygnowano także z obróbki cieplnej kadłubów czołgów po spawaniu [9]. Gdy skończyły się zapasy topnika AN-1 produkowanego w zajętym przez Wehrmacht Donbasie, opracowano „wojenny” topnik ASz-1 złożony z wolnego od siarki żużla z pieców metalurgicznych opalanych węglem drzewnym oraz rudy manganowej [10].

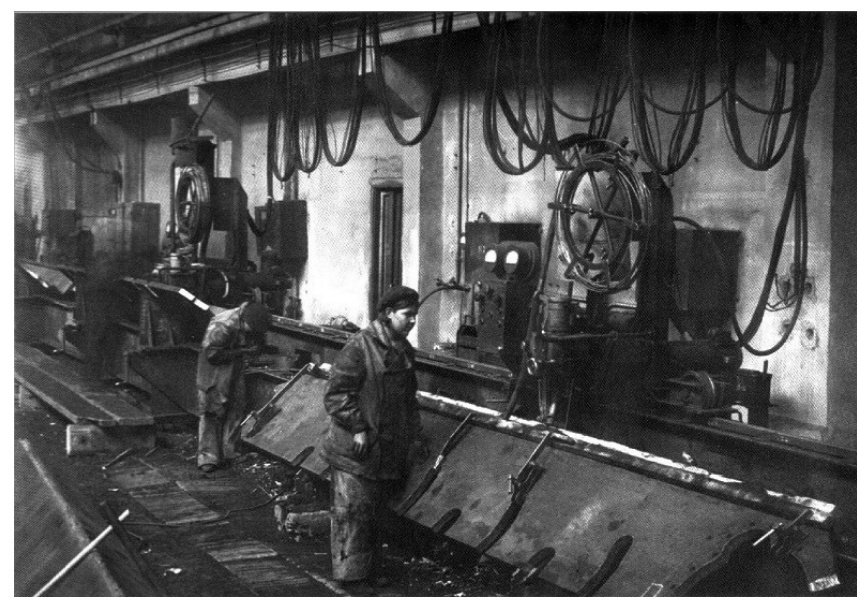

Rys. 7. Spawanie burty czołgu T-34 [36] Fig. 7. Welding of the T-34 tank side [36]

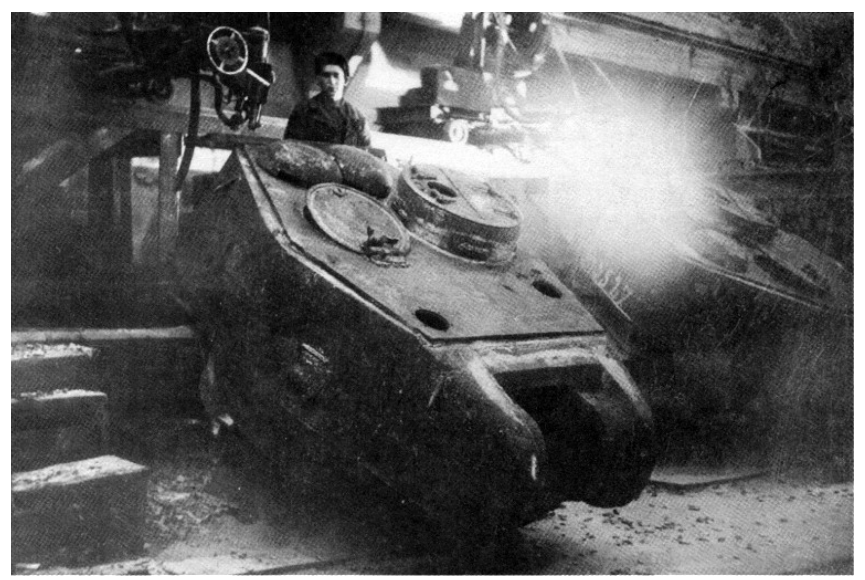

Rys. 8. Spawanie pod topnikiem stropowej płyty wieży T-34 z odlewanym korpusem wieży (odblask to uszkodzenie negatywu, a nie światło łuku) [36]

Fig. 8. Submerged arc welding of the T-34 tank turret roof with the cast turret walls (reflection is a damage to the negative, not the light of the arc) [36] 
USA

Równolegle i niewykluczone, że pod wpływem informacji o pracach Sławianowa, nad tym samym zagadnieniem pracowano w USA. Pierwszym praktycznym zastosowaniem było opracowanie przez National Tube Company metody wydajnego wzdłużnego spawania rur w fabryce w McKeesport w Pensylwanii. Technologia została opatentowana przez B. Robinoffa (emigranta z Rosji Borisa Robinova) w tym samym roku [11], a później, w 1935 r. sprzedana firmie Linde Air Products Company, która nazwała ją metodą Unionmelt i zorganizowała jej sprawny marketing. Rozwiązania Robinoffa dość szybko zaczęto krytykować, zarzucając m.in. niewłaściwy wybór topników, które powodowały silne dymienie, zmuszające spawaczy do noszenia masek przeciwgazowych (!) [12].

W jednym z listów prezydenta USA F.D. Roosevelta do W. Churchilla, który dotyczył perspektyw wsparcia brytyjskiego wysiłku wojennego, pojawiło się stwierdzenie, że w USA jest od niedawna stosowana "metoda spawania, która pozwala na budowę statków z nieporównywalną (z dotychczas stosowanymi technologiami) szybkością, większą do 20 razy" [13].

O zastosowaniach metody Unionmelt pisano niewiele - w 1937 r. zasygnalizowano jej użycie do spawania ramy wagonu kolejowego [14] oraz kadłuba zbiornikowca [15]. Dopiero po wojnie ujawniono, że w połowie lat 40. w USA było ponad 800 użytkowników metody, stosowanej głównie w przemyśle okrętowym. Np. w trakcie budowy transportowca typu Liberty wykonywano ok. $60 \mathrm{~km}$ spoin, z czego $20 \%$ stanowiły połączenia wykonane metodą Unionmelt [16].

Także firma Lincoln Electric uruchomiła produkcję własnego urządzenia nazwanego Hidden Arc i została pozwana przez Linde APC za naruszenie praw patentowych. Proces rozstrzygnął dopiero w 1949 r. Sąd Najwyższy USA (!) uznając roszczenia za częściowo zasadne.

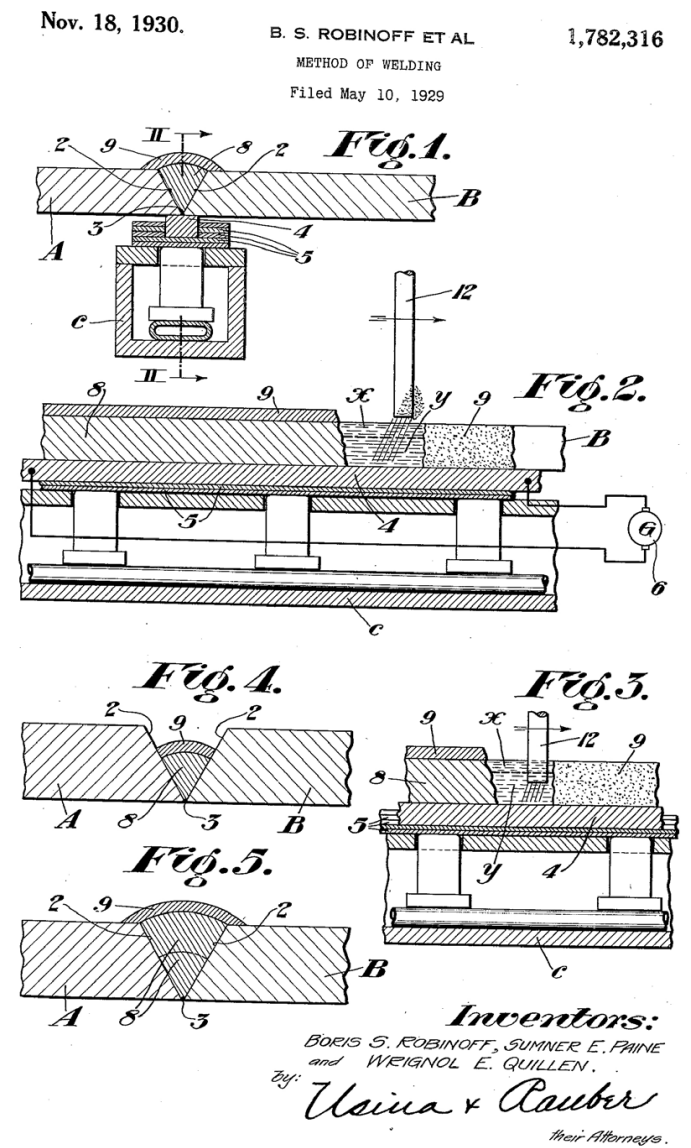

Rys. 9. Rysunek z patentu Robinoffa - dobrze widoczny skomplikowany układ pozycjonowania podkładki kształtującej grań [11] Fig. 9. Drawing from the Robinoff patent - the complex root forming device is clearly visible [11]

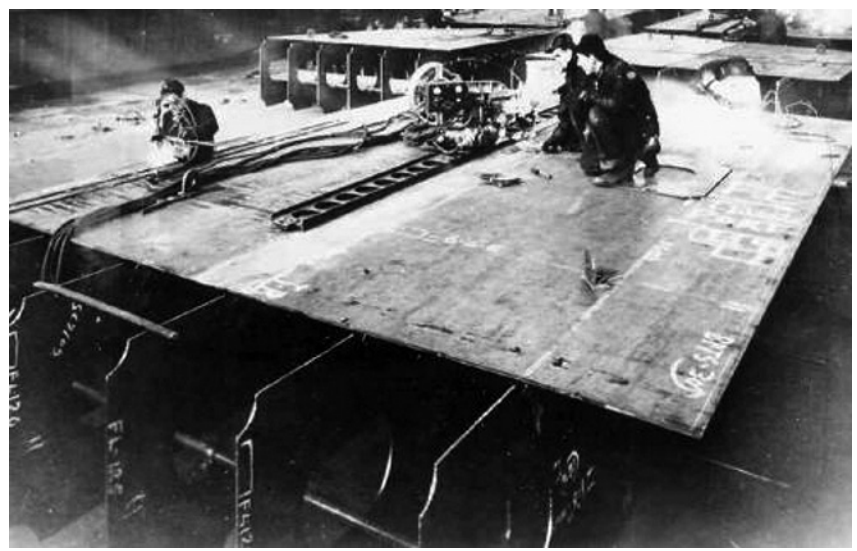

Rys. 10. Spawanie sekcji płaskiej kadłuba statku typu Liberty w USA. Fot. arch. autora

Fig. 10. Welding of the section of a flat hull of a Liberty type ship in the USA. Fig. author's archives

\section{Niemcy}

W Niemczech spawanie łukiem krytym zaczęto stosować w 1937 r. od zakupu licencji na amerykańską metodę Unionmelt. Nabyła ją firma Gesellschaft für Lindes Eismaschinen AG z Höllriegelskreuth i wprowadziła na rynek pod nazwą Ellira (Elektro-Linde-Rapid) [17]. Natomiast firma Kjellberg opracowała automat do spawania łukiem krytym UPG „Maulwurf" (kret) na bazie swego automatu do spawania nieosłoniętym drutem [18]. Spawanie łukiem krytym wdrażano między innymi w przemyśle stoczniowym [19], który wcześniej opanował spawanie sekcji kadłubowych elektrodami otulonymi.

\section{Spawanie elektrożużlowe}

Z technologii spawania łukiem krytym wywodzi się wprost technologia spawania elektrożużlowego, stworzona w celu spawania konstrukcji o jeszcze większej grubości. Powstała ona po II Wojnie w kijowskim Instytucie Elektrosvarki [20]. Także i tę technologię planowano zastosować w celach militarnych i dlatego utrzymywano fakt jej istnienia w tajemnicy

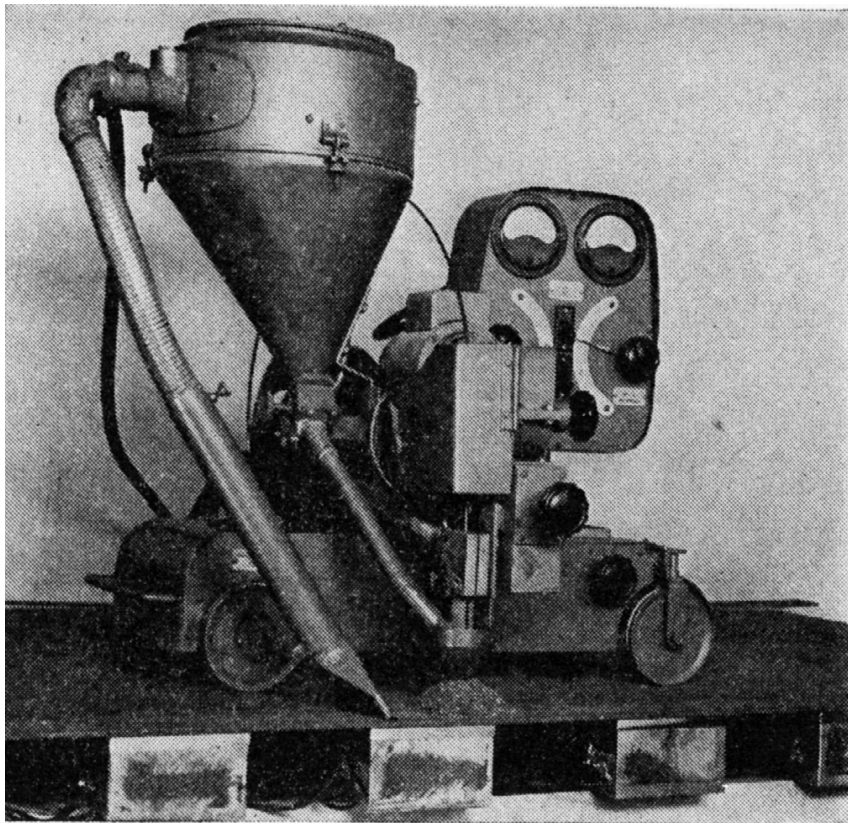

Rys. 11. Automat Elirra IV [19]

Fig. 11. Ellira IV automated submerged arc welding machine [19] 


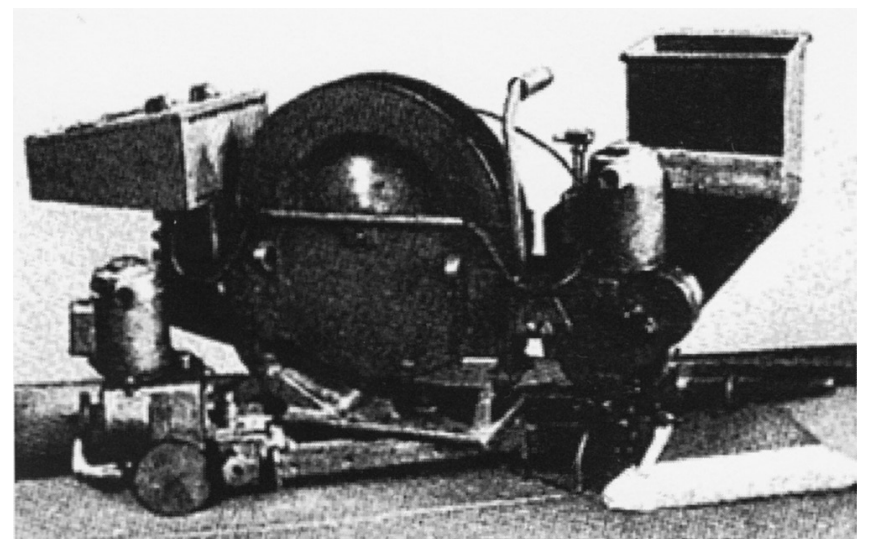

Rys. 12. Automat Maulwurf - widoczny „odkurzacz” zbierający nadmiar topnika i odprowadzający go z powrotem do zasobnika [17] Fig. 12. Maulwurf submerged arc welding machine - visible "vacuum cleaner" collecting excess flux and draining it back to the tray [17]

przez ponad 7 lat - ujawniono ją dopiero w 1958 r., kiedy empirycznie sprawdzono, że nie nadaje się do spawania wysokowytrzymałych blach pancernych.

\section{Spawanie łukiem krytym w Polsce}

W Polsce technologię spawania łukiem krytym zaczęto wdrażać po zakończeniu wojny (informacje o zakupie krótko przed wojną kilku urządzeń na potrzeby produkcji specjalnej w COP wymagają potwierdzenia), ale w 1954 r. w kraju było tylko ok. 30 urządzeń o tym przeznaczeniu importowanych z ZSRR (ADS-1000-1 i ADS-1000-2) oraz z NRD (Kjellberg UPU) [21]. Pierwsza polska konstrukcja - AS3-500, powstała w 1953 r. w CBKME była kopią radzieckiego półautomatu PSz-5 [22]. Była to jednak "ślepa uliczka” w rozwoju tej technologii, czyli spawanie zmechanizowane. „Półautomat spawalniczy" zapewniał jedynie zmechanizowane podawanie drutu o średnicy do $2 \mathrm{~mm}$, a maksymalny prąd spawania wynosił 600 A [23]. Spawacz ręcznie prowadził głowicę w postaci masywnego pistoletu z zasobnikiem topnika wzdłuż linii spawania nie widząc łuku, nie znając rzeczywistej odległości elektrody od jeziorka spawalniczego itp. Miał to być sposób na wykonywanie spoin krzywoliniowych, których nie dało się wykonywać z zastosowaniem ówczesnych urządzeń zautomatyzowanych, zdolnych do spawania jedynie wzdłuż linii prostej. Żeby choć trochę ułatwić nadążanie za przebiegiem szczeliny spawalniczej głowice zaopatrywano w niewielkie lampki, rzucające plamkę światła na materiał przed obszarem pokrytym topnikiem.

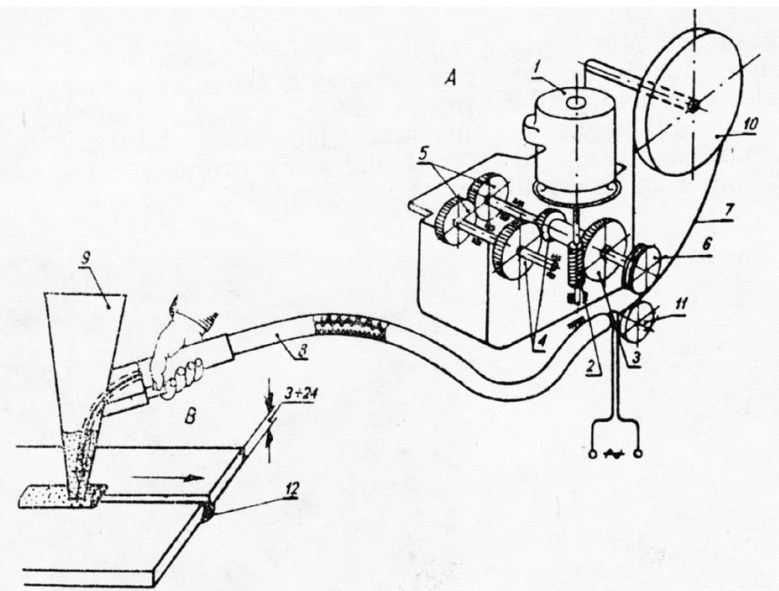

Rys. 13. Schemat urządzenia do półautomatycznego spawania łukiem krytym [23]

Fig. 13. Diagram of a semi-automatic submerged arc welding device [23]

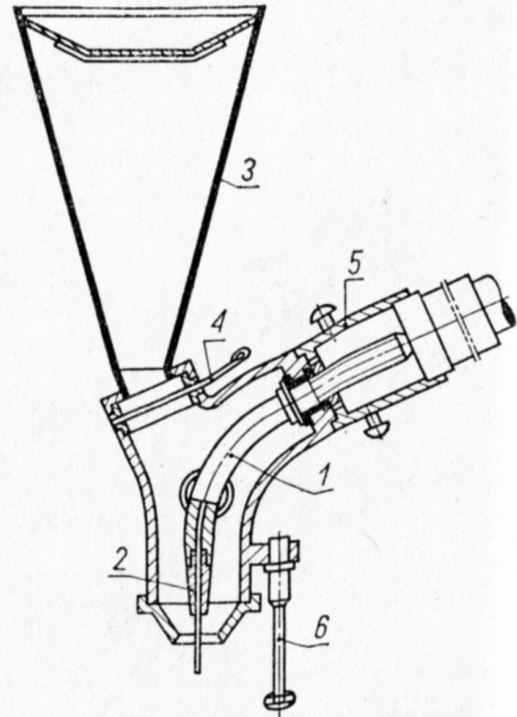

Rys. 14. Uchwyt polskiego urządzenia AS3-500 [23]

Fig. 14. Holder of the Polish AS3-500 device [23]

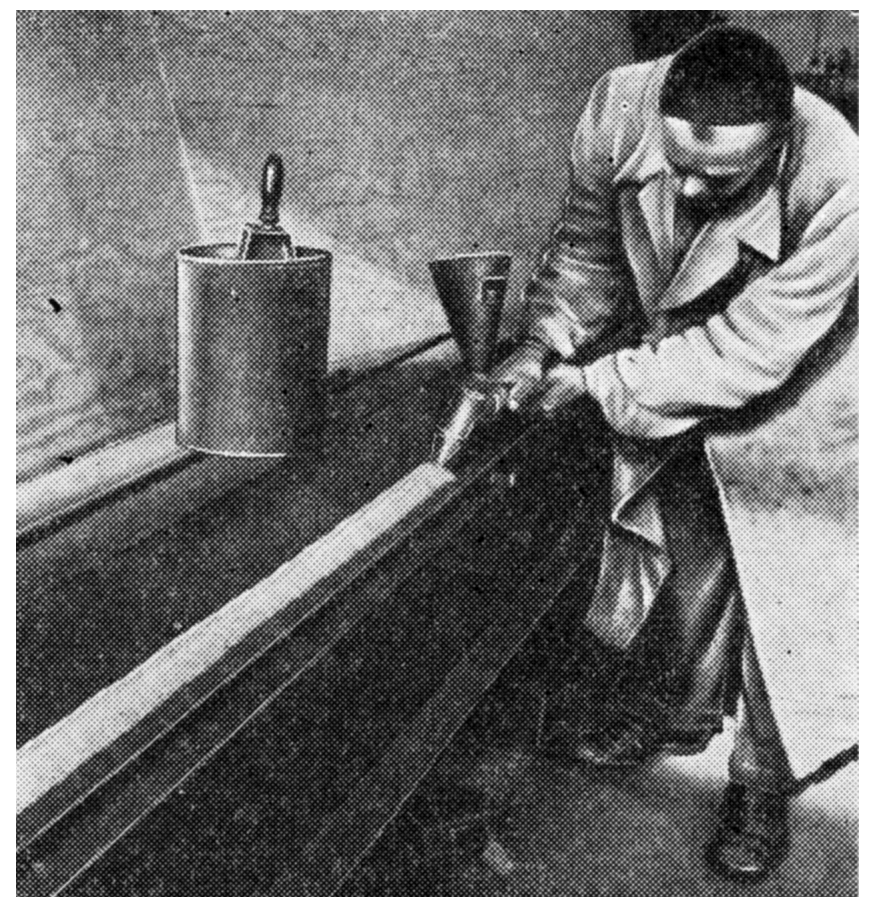

Rys. 15. Spawacz przy pracy urządzeniem AS3-500 [23]

Fig. 15. Welder at work with the AS3-500 device [23]

Pierwsza zwarta polska publikacja, poświęcona temu zagadnieniu pojawiła się w 1955 r. [24]. Publikowano na ten temat relatywnie liczne artykuły, a w Poradniku Inżyniera - Spawalnictwo z 1970 r. spawaniu łukiem krytym poświęcono aż 42 strony.

Pierwszy polski automat spawalniczy AS1-1250 zaczęto produkować w połowie lat 50 . ub. wieku. Była to kopia urządzenia radzieckiego UT-1250, opracowana wspólnie przez Centralne Biuro Konstrukcyjne Maszyn Elektrycznych (CBKME) i Instytut Spawalnictwa. Wyprodukowano takich urządzeń tylko kilkadziesiąt, a ich praktyczne zastosowanie napotkało na poważne trudności, wynikające oficjalnie z dużych gabarytów i zawodności, a w praktyce w znacznym stopniu z braku kwalifikacji i konserwatyzmu użytkowników [25]. Kolejne urządzenie: AS7d-1200 było już polską konstrukcją i zapewniało napięciową samoregulację długości łuku [26]. Prototyp powstał w Instytucie Spawalnictwa w 1956 r., ale nie znaleziono dla niego producenta i wytwarzaniem obarczono ZBPUS - Zakład Budowy Prototypów 
Urządzeń Spawalniczych Instytutu. Kilka kolejnych konstrukcji (AS-8a, AS-11a-600 i in.) pozostało prototypami i dopiero AS14-1200 opracowany w 1966 r. był produkowany seryjnie przez OZAS Opole [18].

Podobnie trudne były początki krajowej produkcji materiałów dodatkowych. Receptury dla nich zostały opracowane w Instytucie Spawalnictwa w latach 1952 $\div 1953$, ale wytwórcy topników nie znaleziono i produkcję materiałów z rodziny TMn oraz TK na skalę "półtechniczną" prowadzono w Instytucie aż do 1960 r. [28]. Twórcą krajowych receptur topników do spawania łukiem krytym był Edward Chuchro [29].

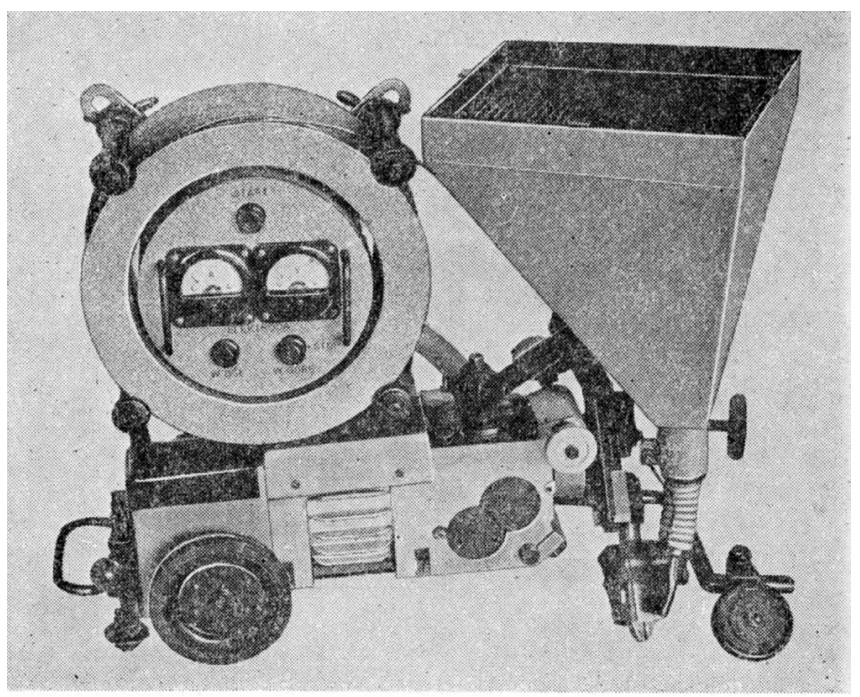

Rys. 16. Prototyp automatu AS1 1a-600 [23]

Fig. 16. AS11a-600 machine prototype [23]

\section{Spawanie metali nieżelaznych}

Spawanie miedzi i jej stopów łukiem krytym zainicjował Dulczewski. We współczesnej literaturze fachowej jest ono pomijane milczeniem [30], ale np. jeszcze w „Poradniku Inżyniera Spawalnictwo" z 1983 r. zostało napisane o nim, jako o „praktycznie zaniechanym” ze względu na trudność w dobraniu odpowiedniego topnika i problemami z doborem podkładek kształtujących grań (najwyraźniej chodzi o niemożność użycia podkładek miedzianych) [31]. Tymczasem Instytut im. Patona z Kijowa oferuje obecnie spawanie pod topnikiem nie tylko miedzi i jej stopów, ale i miedzi ze stalą [32], co oznacza, że proces ten został $w$ pełni opanowany, podobnie, jak dobór i produkcja odpowiednich topników, np. OSC-45 lub K-13. Spawanie jest prowadzone prądem stałym z odwrotną polaryzacją, zalecane są grafitowe podkładki kształtujące grań. Do spawania prądem przemiennym zalecany jest topnik ŻM-1.
Spawanie łukiem krytym stopów aluminium nie było praktykowane na skalę przemysłową, choć testowano taką możliwość. Między innymi w Zakładzie Spawalnictwa Politechniki Wrocławskiej nie bez powodzenia realizowano takie próby na przełomie lat 70 . i 80 . ub. wieku równolegle z pracami, dotyczącymi elektrożużlowego spawania aluminium [33].

Technologię spawania łukiem krytym stopów tytanu zaczęto rozwijać w Instytucie Elektrosvarki w Kijowie w połowie lat 50. ub. wieku [34], czyli wcześniej, niż rozwinęła się przemysłowa produkcja tego metalu na większą skalę. Co ciekawe, od początku zakładano, że metoda będzie stosowana do elementów o grubości znacznie mniejszej, niż w przypadku stali. Wynikało to zapewne ze świadomości, że zapotrzebowanie na grubościenne spawane konstrukcje tytanowe będzie niewielkie. Uznano, że kluczem do sukcesu jest zastosowanie beztlenowych topników z minimalną możliwą zawartością tlenków. Po próbach do spawania elementów o grubości do $6 \mathrm{~mm}$ opracowano topnik ANT-1 zawierający znaczną ilość chlorków i zapewniający wysoką jakość lica spoiny. Do grubszych blach stosowano topniki ANT-3 i ANT-7 zawierające znaczne ilości $\mathrm{NaF}, \mathrm{CaF}_{2}$ i BaCL 2 . Jako materiał dodatkowy stosowano czysty tytan, a prędkość spawania wynosiła $40 \div 60 \mathrm{~m} / \mathrm{h}$. Dalsze ograniczenie dostępu tlenu do jeziorka miało zapewnić przedmuchiwanie topnika argonem, co było rozwiązaniem unikatowym [35]. Ostatecznie, mimo zadawalających wyników wytrzymałościowych, spawanie stopów tytanu pod topnikiem nie znalazło szerszego praktycznego zastosowania.

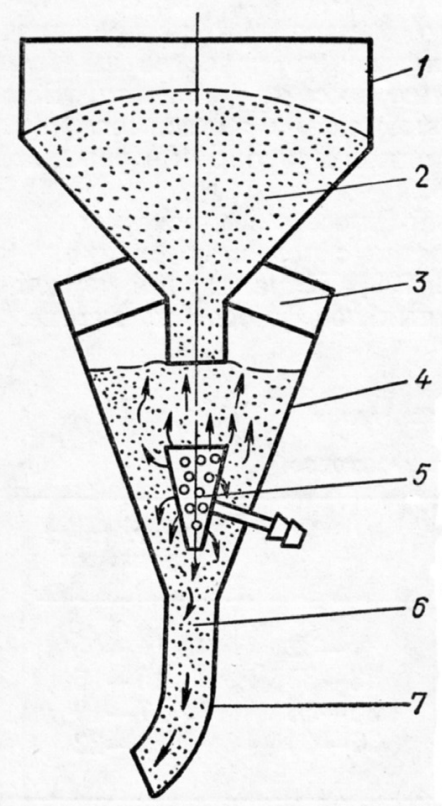

Rys. 17. Zasobnik topnika do spawania tytanu, numerem 5 oznaczony zespół dysz do nadmuchu topnika argonem [35]

Fig. 17. A flux tank for titanium welding, a set of nozzles for blowing flux with argon was marked as number 5 [35]

\section{Podsumowanie}

Spawanie pod topnikiem, które dojrzało do praktycznego stosowania nieco wcześniej, niż spawanie elektrodą nietopliwą w osłonie gazów obojętnych, stanowiło jeden z kamieni milowych na drodze rozwoju spawania łukowego. Była to pierwsza metoda umożliwiająca zautomatyzowane spawanie z wysoką wydajnością i zapewniające dobrą i powtarzalną jakość spoin. Chociaż obecnie jest stosowane niemal wyłącznie do spawania stali, zwykle tylko w pozycji podolnej, to jego udział w produkcji konstrukcji spawanych, szczególnie grubościennych, jest ciągle bardzo znaczący. 


\section{Literatura}

[1] Električeskaja otlivka metalov gornogo inženiera Nikolaja Slavianova, Sankt Petersburg 1891.

[2] Musin R.: N.G. Slavianov i razvitie jego idiej na rodinie rossijskoj elektrosvarki, Izd., PermGTU, Perm 2004

[3] Slavianov N.G.: Trudy i izobretienia, Knižnoje izd., Perm 1988.

[4] Dulczewski D.: Opisanie sposoba dugovoj električeskoj svarki medi, Patent na izobretienie nr 10579, Moskva 1929.

[5] Potapov N.: Osnovy vybora fljusov pri svarke stalej. Mašinostrojenie, Moskva 1979.

[6] Diatlov V.: Sposob avtomatičeskoj dugovoj svarki pod sloem fljusa. Opisanie izobretienia k avtorskomu sviditielstvu nr 64207, Moskva 1945.

[7] Spielberger W., Doyle H.: Tigers I and II and their variants, Schiffer Publ. Atglen, USA 2007.

[8] Solyankin A., Zeltov I., Kudriasov K.: Otečestvennyje bronirovannyje mašiny. XX vek. Tom 3, Cejhgauz, Moskva 2010.

[9] Paton B., Kornijenko A.: Ogon smiešivajet metal, Izd. Pedagogika, Moskva 1980.

[10] Paton B.: Sovremennoje sostojanie avtomatičeskoj svarki pod fljusom - itog razvitia idiej N.G. Slavianova, Materiały konferencyjne, Masgizdat, Kiev 1955.

[11] Robinoff B., Paine S., Quillen W.: Method of welding, US Patent no.1,782,316. 1930

[12] Simonson R.: The history of welding, Monticello Books Inc, Morton Grove, USA 1969.

[13] Irving B.: Welding's vital part in major American historical events, Welding Journal 06, 1999.

[14] Pullman Standard active in welding developments, The Welding Engineer no. 9, 1937.

[15] Jackson T.: Welding in tanker construction, The Welding Journal 1937 no. 10.

[16] Health of arc welders in steel ship construction, US Surgeon General Review 1947.

[17] Bernsdorf G.: Auf heissen Spuren vom Schmieden, Loeten, Schweissen, VEB Fachbuchverlag, Leipzig 1986.
[18] Beckert M.: Grundlagen der Schweisstechnik-Schweissverfahren, VEB Verlag technik, Berlin 1983.

[19] Krekeler K., Schmidt-Bach H.: Das Schweissen im Schiffbau (repr.), Unikum Verl., Bremen 2011.

[20] Paton B. (red.): Electroslag Welding and Surfacing, Mir, Moskwa 1983.

[21] Pilarczyk J.: Kierunki rozwojowe spawalnictwa w Polsce, Przegląd Spawalnictwa $\mathrm{nr}$ 1, 1955

[22] Mausolf E., Unterschuetz Z.: Mechanizacja prac spawalniczych na tle osiągnięć Stoczni Gdańskiej, Przegląd Spawalnictwa nr 3, 1957.

[23] Poradnik Spawalniczy wyd. 3, WNT, Warszawa 1970.

[24] Węgrzyn I., Korkiewicz R.: Automatyczne spawanie łukiem krytym, PWT, Warszawa 1955.

[25] Korkiewicz R.: Aparatura do spawania automatycznego, Przegląd Spawalnictwa $\mathrm{nr}$ 3, 1957.

[26] Sokołowski S.: Nowy automat do spawania łukiem krytym, Biuletyn Informacyjny Instytutu Spawalnictwa nr 4, 1958.

[27] Turyk E. Grobosz W.: Początki metody spawania łukiem krytym, Biuletyn Instytutu Spawalnictwa, nr 3, 2014.

[28] Szczeciński Z.: Kronika Instytutu Spawalnictwa z lat 1945-96, Gliwice 1998.

[29] Kubiszyn I., Pilarczyk J.: 40-lecie Instytutu Spawalnictwa, Przegląd Spawalnictwa nr 7-8, 1985.

[30] Poradnik Inżyniera Spawalnictwo T. 1, WNT, Warszawa 2003.

[31] Poradnik Inżyniera. Spawalnictwo T. 2, WNT, Warszawa 1983.

[32] www.paton.kiev.ua/progresivni... dostęp 2018.

[33] Sobieralski R.: Wpływ własności fizycznych topników na przebieg i wyniki spawania elektrożużlowego aluminium, Rozprawa doktorska, Wydział Mech. Politechniki Wrocławskiej 1986.

[34] Gurievic S.: Nekotoryje osobennosti svarki titana pod fljusom, Avtomatičeskaja Svarka nr 5, 1957.

[35] Gurievic S. (red.): Metallurgia i technologia svarki titana i jego splavov, Naukova Dumka, Kiev1979.

[36] Archiwum Urałwagonzawoda, Niżny Tagił. 